\title{
HISTORICAL ANALOGIES, GENERATIONAL EFFECTS, AND ATTITUDES TOWARD WAR*
}

\author{
HowARD SCHUMAN \\ University of Michigan
}

\author{
CHERYL RIEGER \\ University of Michigan
}

\begin{abstract}
Debates over initiating war with Iraq turned to a considerable extent on which of two analogies from the past were most relevant: World War II or the Vietnam War. Along with three other theoretical conditions, the debate provided an unusual opportunity to develop and assess important implications of Mannheim's theory of generational effects. National data gathered before the war and during the war indicate that generational experience had a significant effect on which analogy was chosen as more relevant and that the analogy chosen had, in turn, a strong relation to support for or opposition to the war. However, the translation of generational experience into final support for or opposition to the war was weak. Reasons for the weak relationship are discussed.
\end{abstract}

$\mathrm{T}$ he assumption that attitudes and behavior are shaped by the common experiences of a cohort - what has often been called a generation - has long had intuitive appeal to sociologists. The appeal was sharpened by Mannheim's ([1928] 1952) eloquent argument that generations can be identified in terms of events experienced during the years of adolescence and early adulthood - ages 17 to 25 , according to Mannheim - and the suggestion that such generational or cohort effects are comparable in importance to effects based on social class. ${ }^{1}$

However, the existence of cohort effects of this type has received little support from systematic research examining lasting associations between political events occurring during adolescence and early adulthood and present political and social attitudes and behavior. Connections have been documented for small activist and elite groups (Jennings 1987; Marwell, Aiken, and Demerath 1987; Alwin, Cohen, and Newcomb 1991), but the results have been largely negative for the wider population (Barnes 1972; Converse 1987; Holsti and Rosenau 1980) or, when positive, not enduring in the face of political change (Weil 1987). Reflecting on the negative findings,

\footnotetext{
* Direct correspondence to Howard Schuman, Institute for Social Research, P.O. Box 1248, Ann Arbor, MI 48106. We received useful suggestions on earlier versions of this paper from Katherine Bischoping, Philip E. Converse, James A. Davis, John E. Mueller, and Yu Xie. Part of the funding for the research came from a grant from the National Institute of Aging (1 RO1 AG08951).

${ }^{1}$ We use "generation" here as approximately equivalent to the term "cohort." Those who prefer that gen-
}

Converse (1987) suggested that the lack of connection between past experiences and present attitudes is simply a further example of the fact that the mass public does not show a stable organization of beliefs and attitudes at the individual level (Converse 1964). If this is correct, there is little reason to expect political events experienced during youth to have the kind of permanent impact on later attitudes that Mannheim assumed.

In view of the empirical evidence and theoretical reasoning, it seems best to treat what Mannheim considered to be distinctive generational experiences as merely potential sources of present attitudes and behaviors, and to explore theoretically the conditions that might stimulate a cohort to connect its experienced past with present problems. Much as certain subatomic particles can be identified only under extreme physical conditions, an unusual conjunction of social conditions might show Mannheim's argument to be theoretically sound, even though much overstated when applied to most issues confronting the public.

One obvious condition for generational effects is that a past event must have made a lasting impression on the memories of those who expe-

eration be limited in meaning to "the temporal unit of kinship structure" (Ryder 1965, p. 853) can substitute the term cohort wherever we have used generation. We think there is value, however, in maintaining a link with the work of Mannheim and others for whom the term generation suggested a shaping of beliefs by a historically significant period. We use both terms at the beginning and end of this article, but employ the term cohort throughout our analysis. 
rienced it during their youth. Two events that fulfill this condition well for Americans were World War II and the Vietnam War. In a recent study of collective memories, Schuman and Scott (1989) found these to be the two most frequently reported events when a national sample of Americans was asked in 1985 to mention "events and changes" from the past 50 years that seemed to them "especially important."2 Moreover, mentions of the two wars showed striking generational effects: World War II was mentioned disproportionately by those in their late $50 \mathrm{~s}$ and $60 \mathrm{~s}$, and the Vietnam War by those in their 30 s and early 40 s - the two cohorts that were in their youth, respectively, during the two wars.

A second condition for generational effects on current attitudes is that this impression from the past be consensual enough that most people regard the event in a similar way, at least at some level of collective memory. There is little doubt that World War II is widely viewed as having been a "good war" with clear moral aims and a victorious outcome. It is also true that the Vietnam War left a much more negative impression on the public, a sense that it failed to achieve any meaningful goal despite the loss of many American lives. Although there are different views as to why the Vietnam War was a "mistake," the sense of a failed military involvement in a distant Asian country is broadly held. This general consensus is reflected in the attraction of the Vietnam Memorial: The long list of the dead and the absence of images of victory symbolize something tragic to all who view it, regardless of the different answers they might give to the "why" question (Wagner-Pacifici and Schwartz 1991). Furthermore, a recent national survey found that 89 percent of the American public regarded World War II as a "just" war, while the corresponding figure for the Vietnam War was only 25 percent (The Gallup Poll Monthly, Feb. 1991, p. 21).

A third condition is that the current event must capture public attention so that most people feel a pressing need to develop beliefs and attitudes toward it. Such an event was provided by the crisis in the Persian Gulf that occurred when Iraq suddenly occupied Kuwait on August 2, 1990. The decision by the American President to send troops to Saudi Arabia drew immediate public

\footnotetext{
${ }^{2}$ The Korean War, on the other hand, was twentieth in number of mentions, referred to by only 2 percent of the sample, as against 29 percent for World War II and 22 percent for Vietnam. The Korean War was not invoked in the public debate that concerns us here.
}

attention and, in the days that followed, television and other media focused on the Persian Gulf to the exclusion of almost all other news. Accounts of the scope of the military effort and the hardships facing troops suddenly plunked down in a vast desert were vividly portrayed on television night after night. According to a Gallup Poll in December 1990, 89 percent of the American public claimed to be following the news from the Persian Gulf "very closely" or "fairly closely," with only 9 percent saying "not too closely" and a mere 2 percent saying "not at all" - an extraordinary set of figures for any political event (The Gallup Poll Monthly, Feb. 1991, p. 6). Thus the crisis in the Gulf met the third condition of a sharp focus on a current political issue in a stunning fashion.

A final condition for broadly felt cohort effects is based on the assumption that most people do not spontaneously dwell on historical analogies when attempting to understand a present problem. Instead, analogies to past events are often made salient by those who attempt to shape support for a particular policy. Exactly this happened for the Persian Gulf crisis: During the course of an open, dramatic, and lengthy debate, leading figures on both sides called on the lessons of history to explain and justify their positions. The President - himself a member of the World War II generation - explicitly and repeatedly compared Iraq's leader Saddam Hussein to Adolf Hitler and likened Iraq's action to the Nazi conquest of small neighboring countries prior to World War II (Smith 1992). Other government leaders echoed the analogy, using it to argue for early American military intervention. In contrast, those who opposed offensive military action drew heavily on the American experience in Vietnam to explain their view. For example, Senator Bob Kerrey - speaking as a Medal of Honor veteran wounded in Vietnam told the Senate Armed Services Committee: "I believe that if we launch a military offensive, we will sustain thousands of casualties without military necessity, moral justification, or public endorsement" (Toner 1991, p. 51). Invocations of Vietnam probably had different meanings to different listeners: For most people, Vietnam suggested the likelihood of many American deaths in a war that could be far easier to begin than to win, though for others it may have meant the grievous effects of military violence for all sides in a conflict, regardless of the outcome.

These two analogies - to Hitler's Germany and to the Vietnam quagmire - were presented 
over and over during the nearly six months between Iraq's August invasion and the start of American bombing of Iraq on January 16, 1991. If we combine the public debate with the other conditions discussed and consider again Mannheim's generational theory, we can hypothesize that Americans who went through adolescence or early adulthood during World War II or in the years between that war and the Vietnam War would be more likely to find the analogy to World War II most appealing. Those who went through the same life stages during the Vietnam era or in subsequent years should be more likely to see the Vietnam analogy as compelling. In sum, the Persian Gulf crisis satisfies what appear to be the major theoretical conditions for producing connections based on generational experience.

We use current age to locate cohorts in relation to these two wars. However, in order to treat age as an unambiguous indicator of cohort experience, we must assume that the biological and social changes that accompany the life cycle have no systematic effects on directly relevant attitudes. There is increasing evidence to support this assumption for a number of attitudes (Alwin et al. 1992; Danigelis and Cutler 1991; Davis 1975; Krosnick and Alwin 1989). Furthermore, empirical evidence on the relation between age and support for past wars does not show a single direction - though over recent decades older Americans have been less supportive of military action - the reverse of our prediction in the case of the Persian Gulf. Mueller (1973, App. A) examined 22 surveys carried out during the Vietnam War and 23 conducted during the Korean War. He found that in every survey older Americans were less supportive of war than younger Americans. This suggests that the same thing might well be true for support for American military action in the Persian Gulf. However, Cantril (1951) provided a datum for males from 1941 that showed a positive relationship between age and willingness to enter World War II against Germany and Italy, though the prowar percentages for all ages were quite small and there was no relationship for females. This lack of agreement makes us hesitate to treat aging per se as a source of attitudes toward military action; however, if the Vietnam and Korean data are considered more decisive than the single result from World War II, then the negative relation of age to support for military action would tend to offset the predicted generational effects.

\section{POSING THE QUESTION}

Beginning in October 1990 and continuing through most of February 1991, we asked respondents in monthly national cross-section samples the following three questions. ${ }^{3}$

Now I'm going to read you two comparisons people are making about the current situation in the Middle East. For each, please tell me your first reaction whether it is a good way to look at the situation, or it is not such a good comparison.

1. First, Saddam Hussein of Iraq is like Adolf Hitler of Germany in the 1930s and it is important to stop him now or he will just seize one country after another. Is that a good way to look at the situation or is that not such a good comparison?

2. The second comparison is that getting involved with Iraq in the Middle East is a lot like getting involved in Vietnam in the 1960s and a small commitment at first can lead to years of conflict without clear results. Is that a good way to look at the situation or is that not such a good comparison?

3. Which of the two comparisons do you think best fits the Middle East situation with Iraq - the comparison to Hitler and Germany in the 1930s or the comparison to Vietnam in the 1960 s?

The first two questions present the Hitler and Vietnam analogies, but have the weaknesses of giving only one analogy at a time and having an agree/disagree format that sometimes leads to acquiescence bias. Their main function was to ensure that respondents were exposed to each historical analogy before being asked the third question that required a clear choice between the two. ${ }^{4}$ (We used split-ballot experimentation to

${ }^{3}$ These were random digit dial telephone samples of the contiguous United States. Each month a new sample of approximately 300 adults 18 years of age and over was interviewed. Our questions were added to a regular Omnibus Monthly survey carried out by the University of Michigan's Survey Research Center and were not preceded by any other questions related in content, except as noted below. Response rates over the five months were 71 percent or 72 percent in each month except December, when the shortened time for interviewing over the holiday period reduced it to 64 percent.

${ }^{4}$ We adapted the first two questions from a $\mathrm{New}$ York Times survey carried out August 9 and 10. We developed the third, forced-choice question. Our results are presented primarily in terms of the forcedchoice question, but the two agree/disagree items lead to essentially the same conclusions, despite some evidence of acquiescence bias associated with low education. Such bias shows up in the fact that although 
Table 1. Responses to Questions About the Persian Gulf War: Before and During the War, 1990-1991

\begin{tabular}{|c|c|c|c|c|c|c|}
\hline \multirow[b]{2}{*}{ Attitude Toward Gulf War } & \multicolumn{4}{|c|}{ Before War } & \multicolumn{2}{|c|}{ During War } \\
\hline & Oct. & Nov. & Dec. & Jan. 1-15 & Jan. $17-28$ & Feb. \\
\hline Percent who agree with Hitler analogy ${ }^{a}$ & $\begin{array}{c}69 \\
(291)\end{array}$ & $\begin{array}{c}67 \\
(280)\end{array}$ & $\begin{array}{c}63 \\
(246)\end{array}$ & $\begin{array}{c}72 \\
(207)\end{array}$ & $\begin{array}{c}70 \\
(77)\end{array}$ & $\begin{array}{c}81 \\
(287)\end{array}$ \\
\hline Percent who agree with Vietnam analogy ${ }^{a}$ & $\begin{array}{c}47 \\
(289)\end{array}$ & $\begin{array}{c}50 \\
(278)\end{array}$ & $\begin{array}{c}52 \\
(248)\end{array}$ & $\begin{array}{c}38 \\
(208)\end{array}$ & $\begin{array}{c}34 \\
(76)\end{array}$ & $\begin{array}{c}22 \\
(281)\end{array}$ \\
\hline \multicolumn{7}{|l|}{ Choice between analogies: } \\
\hline $\begin{array}{l}\text { Percent who prefer Hitler analogy } \\
\text { Percent who prefer Vietnam analogy }\end{array}$ & $\begin{array}{l}58 \\
42\end{array}$ & $\begin{array}{l}57 \\
43 \\
\end{array}$ & $\begin{array}{l}54 \\
46 \\
\end{array}$ & $\begin{array}{l}64 \\
36 \\
\end{array}$ & $\begin{array}{l}75 \\
25\end{array}$ & $\begin{array}{l}82 \\
18\end{array}$ \\
\hline Total percent & $\begin{array}{l}100 \\
(273)\end{array}$ & $\begin{array}{c}100 \\
(249)\end{array}$ & $\begin{array}{c}100 \\
(222)\end{array}$ & $\begin{array}{c}100 \\
(182)\end{array}$ & $\begin{array}{l}100 \\
(69)\end{array}$ & $\begin{array}{l}100 \\
(262)\end{array}$ \\
\hline \multicolumn{7}{|l|}{ Position on war: } \\
\hline $\begin{array}{l}\text { Percent who support Gulf War } \\
\text { Percent who oppose Gulf War }\end{array}$ & - & - & - & $\begin{array}{l}78 \\
22 \\
\end{array}$ & $\begin{array}{l}76 \\
24 \\
\end{array}$ & $\begin{array}{l}88 \\
12 \\
\end{array}$ \\
\hline Total percent & & & & $\begin{array}{c}100 \\
(197)\end{array}$ & $\begin{array}{l}100 \\
(72)\end{array}$ & $\begin{array}{c}100 \\
(278)\end{array}$ \\
\hline
\end{tabular}

a Only the "agree" response is shown; "disagree" is 100 percent minus the percent who agree.

Note: Numbers shown in parentheses are bases of the percentages. All surveys ended on approximately the $27 \mathrm{th}$ of the month, and the remaining interviewing days were part of the next month. The question on support for the Gulf War was not asked in October, November, or December.

rotate the first two questions, so that half of each month's sample received the Hitler question first and half received the Vietnam question first. Question order had no significant effect on results.)

In January 1991, we added a direct question on whether the respondent would support or oppose U.S. military action in the Gulf:

If at some point in early 1991 the President declares that force is necessary to make Iraq withdraw completely from Kuwait, would you favor or oppose such military action?

When the United States began bombing Iraq on January 16 , the question was adapted slightly and the adapted question continued to be asked until our surveys ended on February 26:

The President has now declared that force is necessary to make Iraq withdraw completely from Kuwait. Do you favor or oppose this military action?

Responses to these four questions over the five months, October through February, are summarized in Table $1 .{ }^{5}$ Although the Hitler analogy

the first two items are negatively associated in the total population, as they should be on logical grounds, the association is positive for those with less than a high school degree. This is the classic form of acquiescence by less educated respondents described by Campbell, Converse, Miller, and Stokes (1960).

${ }^{5}$ We omitted interviews done on January 16, the day the war began, since we could not be sure that received somewhat more agreement throughout the entire period than the Vietnam analogy, the forced-choice preference showed a fairly even division through December, a 10 percentage-point jump in preference for the Hitler analogy during the two weeks preceding the bombing, another 11 percentage-point jump in the two weeks after the war began, and a further rise of 7 percentage points during February.

respondents had heard the news. Thus our interviews during the war cover the period from January 17 through February 26. The ground offensive began February 24 and ended February 28, but for practical reasons our interviewing stopped on the 26th and we did not cover the final two days of the war. Omitted from the before-the-war analysis are the following cases: 24 people who insisted that both analogies were "best"; 75 who said "neither"; 34 "don't know"; and 44 "not ascertained" for various reasons (mainly breakoffs in the interview at earlier points before the Iraq questions were asked). The corresponding figures for cases omitted from the during-the-war analysis are: 4, $24,10,16$. Analysis of these missing data categories in relation to education and age indicates that "neither," i.e., rejection of both analogies, which is the largest and probably most substantively meaningful alternative response, was given significantly more often by well-educated respondents than was the case for choice of one of the analogies. "Don't know" and "not ascertained" were recorded most often for older respondents and less educated respondents. 

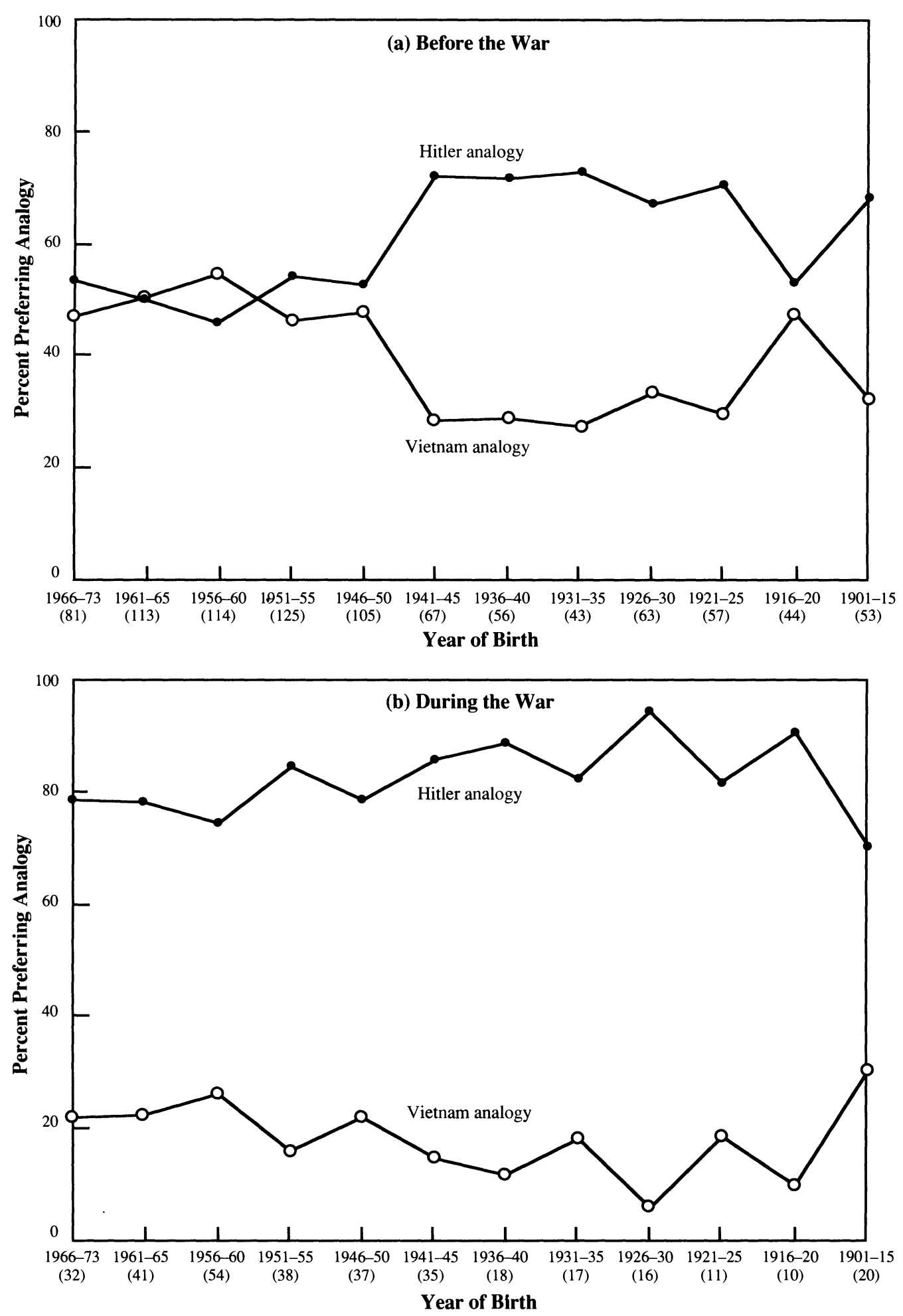

Figure 1. Percentage Preferring the Hitler and Vietnam Analogies by Year of Birth: Before and During the War, 19901991

Note: Numbers in parentheses are bases for percentages. 
Table 2. Logistic Coefficients for Regression of Analogy Preference on Selected Independent Variables: Before and During the Gulf War, 1990-1991

\begin{tabular}{|c|c|c|}
\hline Independent Variable & Before War & During War \\
\hline Age & $\begin{array}{l}.09^{* * *} \\
(.02)\end{array}$ & $\begin{array}{l}.06 \\
(.05)\end{array}$ \\
\hline Education & $\begin{array}{l}-.04 \\
(.06)\end{array}$ & $\begin{array}{l}-.14 \\
(.12)\end{array}$ \\
\hline Gender & $\begin{array}{l}-.29^{*} \\
(.14)\end{array}$ & $\begin{array}{l}-.69^{*} \\
(.32)\end{array}$ \\
\hline Race & $\begin{array}{c}-1.08^{* * *} \\
(.26)\end{array}$ & $\begin{array}{l}-.63 \\
(.54)\end{array}$ \\
\hline Region & $\begin{array}{c}.35^{*} \\
(.15)\end{array}$ & $\begin{array}{c}.25 \\
(.35)\end{array}$ \\
\hline Number of Cases & 864 & 293 \\
\hline${ }^{* *} p<.01$ & \multicolumn{2}{|c|}{${ }^{* * *} p<.001$} \\
\hline \multicolumn{3}{|c|}{$\begin{array}{l}\text { Note: Preference for Vietnam analogy is coded } 1 \text {, prefer- } \\
\text { ence for the Hitler analogy is coded } 2 \text {. Age was coded in } 12 \\
\text { categories from young to old. Education is coded in six } \\
\text { categories: elementary school, some high school, high school } \\
\text { graduate, some college, college degree, post-graduate work. } \\
\text { For gender, men were coded } 1 \text {, women were coded } 2 \text {; for } \\
\text { race, whites were coded 1, blacks were coded } 2 \text {; for region, } \\
\text { non-South was coded } 1 \text {, South was coded } 2 \text {. Numbers in } \\
\text { parentheses are standard errors. }\end{array}$} \\
\hline
\end{tabular}

\section{RESULTS}

\section{Generational Effects on Analogy Preferences}

Our primary interest is in how the choice between historical analogies is related to cohort as operationalized by age. In keeping with previous research, we define "youth" as the teen-age years and early twenties, a slightly wider range than Mannheim assumed, though obviously any particular definition is somewhat arbitrary (Schuman and Scott 1989). The percentage of respondents preferring each historical analogy, by birth cohort, is shown in Figure 1a for the period before the American bombing of Iraq began in mid-January, and in Figure $1 \mathrm{~b}$ for the period after the war began. Although the lines in each figure are complements of each other, both lines are presented in order to show trends more clearly. Table 2 presents the results of logistic regression of analogy preference on age, with controls for background variables, separately for the pre-war and wartime periods.

Before the war. Before the war, approximately 70 percent of older Americans favored the Hitler analogy compared to 30 percent favoring the Vietnam analogy. However, starting with those born in the years 1946-1950, younger Americans chose the Vietnam and Hitler analogies in almost equal proportions. The lines are remarkably stable, despite only moderate sample sizes for each birth cohort and especially for the older cohorts. The dip for those born in the 1916-1920 years is probably best explained as sampling error, though it is worth noting that this cohort reached maturity in the isolationist interwar period rather than during or after World War II. Formally, the regression of preferred analogy on age is positive and clearly significant, with education, race, gender, and region controlled, and there is no sign of a curvilinear relationship when an additional quadratic term for age is included. ${ }^{6}$

The 1946-1950 cohort was the first cohort that was much more likely to choose the Vietnam analogy in the pre-war period. Using their median birth year of 1948, these Americans began adolescence in 1961, before the start of the Vietnam War. They were only 17 in 1965 when the United States began bombing North Vietnam, 20 in 1968 when the Tet Offensive occurred with its devastating effect on American public opinion (Schuman 1972, p. 515), and 25 as the last American troops departed from Vietnam in 1973. This, then, is the cohort that experienced during their youth the largely unquestioned initial support for the Vietnam War, the steady erosion of that support as so many predictions of military success proved false, and the final repudiation of the war, which coincided with the forced resignation of the President who was identified with its end. This cohort also furnished many of the draftees who served in Vietnam, as well as many of the protestors against the war. These facts make this cohort's greater preference for the Vietnam analogy before the war highly plausible. Younger cohorts would have even more negative memories or impressions of the war, as the general population came increasingly to regard American involvement in Vietnam as a mistake.

The relatively smooth lines for the "young" cohorts (born 1946-1973) and for the "old" cohorts (born 1901-1945) suggest the persistence of collective memories beyond an important event. Overall, World War II not only influenced those who grew up during and immediately after the wartime period - its influence extended until the next major war experience, as shown in the long resonance of the Hitler analogy. However, once Vietnam established a new sense of what American involvement in war could mean,

${ }^{6}$ When "month" is added to the pre-war regression, its coefficient does not approach significance, nor does it affect the other coefficients in Table 2. 
Table 3. Cross-Classification of Preferred Analogy by Support for Military Action in the Persian Gulf: Before and During the War, 1990-1991

\begin{tabular}{|c|c|c|c|c|}
\hline \multirow[b]{2}{*}{$\begin{array}{l}\text { Support for } \\
\text { Military } \\
\text { Action }\end{array}$} & \multicolumn{2}{|c|}{$\begin{array}{c}\text { Before War } \\
(\mathrm{N}=172)\end{array}$} & \multicolumn{2}{|c|}{$\begin{array}{l}\text { During War } \\
(\mathrm{N}=318)\end{array}$} \\
\hline & $\begin{array}{l}\text { Prefer } \\
\text { Hitler } \\
\text { Analogy }\end{array}$ & $\begin{array}{c}\text { Prefer } \\
\text { Vietnam } \\
\text { Analogy }\end{array}$ & $\begin{array}{l}\text { Prefer } \\
\text { Hitler } \\
\text { Analogy }\end{array}$ & $\begin{array}{c}\text { Prefer } \\
\text { Vietnam } \\
\text { Analogy }\end{array}$ \\
\hline $\begin{array}{l}\text { Favor military } \\
\text { action }\end{array}$ & $\begin{array}{l}93.7 \\
(104)\end{array}$ & $\begin{array}{l}54.1 \\
(33)\end{array}$ & $\begin{array}{l}94.2 \\
(245)\end{array}$ & $\begin{array}{l}55.2 \\
(32)\end{array}$ \\
\hline $\begin{array}{l}\text { Oppose military } \\
\text { action }\end{array}$ & $\begin{array}{l}6.3 \\
(7)\end{array}$ & $\begin{array}{l}45.9 \\
(28)\end{array}$ & $\begin{array}{l}5.8 \\
(15)\end{array}$ & $\begin{array}{l}44.8 \\
(26)\end{array}$ \\
\hline Total & $\begin{array}{l}100.0 \\
(111)\end{array}$ & $\begin{array}{l}100.0 \\
(61)\end{array}$ & $\begin{array}{l}100.0 \\
(260)\end{array}$ & $\begin{array}{l}100.0 \\
(58)\end{array}$ \\
\hline $\begin{array}{l}\text { Gamma } \\
\text { Standard error }\end{array}$ & & $\begin{array}{l}.85 \\
.06\end{array}$ & & $\begin{array}{l}86 \\
05\end{array}$ \\
\hline Phi & & 47 & & 45 \\
\hline
\end{tabular}

Note: Numbers in parentheses are Ns.

the youth who experienced the war's final years or its aftermath were more likely to think in terms of another Vietnam. Thus, we see societal memory being formed by a profound and pervasive event like a major war - a collective representation that prevails until a new event of equal profundity and pervasiveness sets it on a different course.

Although the construction of the birth cohorts was dictated by the limited number of cases (and developed before viewing the data), an examination of responses for individual birth years from 1946 through 1950 suggests that the transition between 1947 and 1948 provides a good cutting point on a purely empirical basis. Thus, we dichotomized the sample into "old" (born 19011947) and "young" (born 1948-1973) cohorts for some analyses. Cross-tabulating this dichotomy against choice of analogy yields a phi coefficient of $.18(p<.001)$, a relationship that is not large, but is clearly significant.

During the war. Once the war began on January 16,1991 , there was an immediate shift toward the Hitler analogy by the public, as shown in the second graph in Figure 1. A small cohort difference still obtains - those born early in the century average about 6 percentage points higher in their choice of the Hitler analogy than do those born in the post-World War II years. The slightly lower coefficient for age is not distinguishable from the pre-war coefficient - the three-way interaction does not approach significance mainly because of the smaller number of cases available for the during-the-war period. Further- more, when we again dichotomize the cohort variable at 1947/1948, the cross-tabulation with choice of analogy approaches conventional significance levels (phi $=.10, p<.06)$. Thus, the initiation of war increased preference for the Hitler analogy for all cohorts, but it did not entirely eliminate its greater appeal to the older generation compared to the younger generation.

\section{Analogy Preference and Support for the Gulf War}

The two analogies differ in their orientations toward military action in the Gulf: The Hitler analogy argues for early action; the Vietnam analogy argues for caution. Thus, our next question is whether choice between the analogies is associated with support for a military offensive. Table 3 presents a cross-tabulation of the two variables before the war and during the war. ${ }^{7}$ The findings are unusually clear-cut: For both time periods, well over 90 percent of those who chose the Hitler analogy supported offensive action, while the percentage among those who chose the Vietnam analogy was only about 55 during both periods.

The direction in which we have percentaged Table 3 indicates the causal model we believe to be most plausible for these two variables. Although it is not possible to be certain of the causality of two attitudinal measures obtained at the same time, in the case of the formation of an attitude toward a newly perceived problem the natural sequence is that some belief or assertion about the world implies or justifies the new attitude (Fishbein and Ajzen 1975). Few, if any, Americans had thought of supporting an attack on Iraq by the United States before August 2, 1990 , and the underlying justification presented by the President was based almost exclusively on the Hitler analogy (Smith, 1992), even though it also involved such other factors as control of oil resources. Unlike long-standing attitudes, such

\footnotetext{
${ }^{7}$ Because the question on support for military action was not added until our January survey, the number of cases for this and subsequent analyses is much smaller than previously, especially with the need to divide the January sample into the pre- and duringthe-war periods. In both Tables 3 and 4, we include only cases for which data are available for both the analogy question and the favor/oppose war question. Other differences between the two tables occur because of missing data on particular background variables included in Table 4, e.g., when race is included as a predictor, respondents not classified as black or white are omitted.
} 
as aversion to Communism or support for Western Europe, the construction of an entirely new attitude toward war with Iraq required a rationale, whether valid or invalid, specious or profound. (Similar attempts by an earlier President to justify American military intervention in Nicaragua were never very successful because of the lack of a compelling rationale.) Nevertheless, readers who prefer to see Table 3 as reflecting a different or more complex (reciprocal) causality, or no causality at all, can percentage the table in other ways. ${ }^{8}$

Despite the similarity in the associations for the before-the-war and during-the-war periods, Table 3 reveals substantial change: During the two weeks before the war began, 65 percent of the sample preferred the Hitler analogy. This was already an increase over December. But once the bombing was under way the figure jumped to 82 percent $\left(\chi^{2}=17.5, p<.001\right) .{ }^{9}$ What is most striking is that even though a larger percentage of the population surveyed preferred the Hitler analogy after the war began, there is no difference in the percentage of "Hitler" choosers who supported the war. Likewise, the decreased percentage who chose the Vietnam analogy during the war displayed the same level of opposition to the war as did those who chose that analogy before January 16.

An interpretation of this unusual combination of stability and movement can be derived from our knowledge of the different meanings that Vietnam had for the American public. There were two main sources of rising anti-war sentiment in

\footnotetext{
${ }^{8}$ If the preferred causal direction is from favoring or opposing military action to choice of an analogy, row percentages would read, left to right, before the war:
}

$75.9+24.1=100 ; 20.0+80.0=100 ;$

and during the war:

$88.4+11.6=100 ; 36.6+63.4=100$.

If no single causal direction is assumed, or the association between the two questions is thought to be due to a third variable (e.g., rally 'round the President), corner percentages can be used. These would read, from top left clockwise, before the war:

$60.5+19.2+16.3+4.1=101$

and during the war:

$77.0+10.1+8.2+4.7=100$.

${ }^{9}$ The chi-square takes account of differences due to sampling error, but since the early and late January the United States as the Vietnam war moved toward its conclusion in the late 1960s and early 1970s (Schuman 1972). The most important source in terms of numbers occurred because the United States was seen as sacrificing many American lives and yet failing to achieve victory. A much smaller opposition group comprised people who opposed the war regardless of its outcome because of the destruction on both sides. The January bombing of Iraq, in conjunction with a well-orchestrated release of information by the military command, seemed to demonstrate to many Americans the possibility of rapid success with few American casualties - the opposite of the Vietnam experience. Quite likely those who changed from preferring the Vietnam analogy to preferring the Hitler analogy did so as a result of these reports and thus they also shifted from opposition to the war to support of the war.

The relatively small number of respondents who chose the Vietnam analogy and opposed the war after it began must consist, we believe, largely of those whose opposition was based on objections to any conflict in the Persian Gulf, regardless of its outcome in terms of limited American casualties or a decisive American victory. For these people, war in the Gulf was bound to be seen as fundamentally destructive and therefore similar to Vietnam.

Finally, the 55.2 percent in Table 3 who chose the Vietnam analogy in late January or February and yet supported the war seem to pose more of a puzzle. This group may have been made up largely of those who were concerned that the coming ground assault would involve major casualties on the part of the United States, but who felt the war was justified or wished to support the President and the troops. ${ }^{10}$

samples were not independently drawn (though the February sample was), we must further assume that persons interviewed early in the month did not differ in ways we cannot control statistically from those interviewed late in the month. The one background factor that shows a statistically significant difference between pre- and during-war respondents is age. Those interviewed after January 16 were slightly younger on the average than those interviewed before January 16. However, this should have biased responses toward choice of the Vietnam analogy, whereas the opposite occurred.

${ }^{10}$ One interesting group excluded from Table 3 comprises those who rejected both the Hitler and Vietnam analogies - these people tended to oppose military action in almost as high a proportion as those who chose the Vietnam analogy. 
Table 4. Logistic Coefficients for Regression of Support for Military Action in the Gulf on Selected Independent Variables: Before and During the War, 1990-1991

\begin{tabular}{|c|c|c|c|c|}
\hline \multirow[b]{2}{*}{$\begin{array}{l}\text { Independent } \\
\text { Variable }\end{array}$} & \multicolumn{2}{|c|}{ Before War } & \multicolumn{2}{|c|}{ During War } \\
\hline & $\begin{array}{c}\text { Model } \\
1\end{array}$ & $\begin{array}{c}\text { Model } \\
2\end{array}$ & $\begin{array}{c}\text { Model } \\
1\end{array}$ & $\begin{array}{c}\text { Model } \\
2\end{array}$ \\
\hline Age & $\begin{array}{l}-.02 \\
(.07)\end{array}$ & $\begin{array}{l}-.13 \\
(.09)\end{array}$ & $\begin{array}{l}-.03 \\
(.06)\end{array}$ & $\begin{array}{l}-.07 \\
(.07)\end{array}$ \\
\hline Education & $\begin{array}{l}.06 \\
(.19)\end{array}$ & $\begin{array}{l}.10 \\
(.23)\end{array}$ & $\begin{array}{l}-.56^{* * *} \\
(.16)\end{array}$ & $\begin{array}{r}-.54^{* *} \\
(.18)\end{array}$ \\
\hline Gender & $\begin{array}{r}-1.00^{*} \\
(.46)\end{array}$ & $\begin{array}{l}-.93 \\
(.50)\end{array}$ & $\begin{array}{l}-.83^{*} \\
(.40)\end{array}$ & $\begin{array}{l}-.70 \\
(.46)\end{array}$ \\
\hline Race & $\begin{array}{c}-2.83^{* * *} \\
(.78)\end{array}$ & $\begin{array}{r}-1.93^{*} \\
(.86)\end{array}$ & $\begin{array}{l}-.38 \\
(.70)\end{array}$ & $\begin{array}{l}-.11 \\
(.74)\end{array}$ \\
\hline Region & $\begin{array}{l}1.91^{* *} \\
(.68)\end{array}$ & $\begin{array}{l}1.38 \\
(.73)\end{array}$ & $\begin{array}{l}.16 \\
(.43)\end{array}$ & $\begin{array}{c}.08 \\
(.49)\end{array}$ \\
\hline $\begin{array}{l}\text { Analogy } \\
\text { preference }\end{array}$ & - & $\begin{array}{l}2.50^{* * *} \\
(.56)\end{array}$ & - & $\begin{array}{r}2.62^{* * *} \\
(.43)\end{array}$ \\
\hline Number of cases & 164 & 164 & 285 & 285 \\
\hline
\end{tabular}

Note: Opposition to the war is coded 1, support for the war is coded 2. Preference for the Vietnam analogy is coded 1, preference for the Hitler analogy is coded 2. Other variables are coded as in Table 2. Numbers in parentheses are standard errors.

\section{Age, Analogy Preference, and Support for the Gulf War}

Because age is related positively to preference for the Hitler analogy, and preference for the Hitler analogy is related positively to support of military action, a positive relationship between age and support for the war would be expected, all other things being equal. We hypothesized a simple causal model:

\section{Older cohort $\Rightarrow$ Choose Hitler $\Rightarrow$ Support war}

However, Model 1 in Table 4 shows that the relationship of age to support for war with Iraq before January 16 is essentially zero (-.02). Evidence that the positive relationship of age to choice of the Hitler analogy produced a positive effect on support for the war is found in Model 2, which eliminates the effect of analogy preference as an intervening variable by including it in the regression equation. The association of age with support for the war under this condition is more clearly negative $(-.13, p=.07$, one-tailed). The same pattern of difference between the two models occurs to a lesser extent for the post-January 16 responses, lending support to the assumption that choice of the Hitler analogy reduced opposition of older respondents to military action against Iraq, even though we do not find the expected positive relation with support. When we substitute the simple old versus young generational dichotomy for the 12-category age variable in Table 4, the differences in the age coefficients between Models 1 and Model 2 become larger: -.02 versus -.59 before the war, and -.05 versus -.22 during the war, though the differences do not reach significance.

Another informative way to consider the relationship between age and support for the war is to carry out the logistic regressions for Model 1 in Table 4 separately by choice of analogy (not shown). Among respondents who chose the Vietnam analogy, which is where most of the variation in attitudes toward the war occurs, older respondents were significantly more opposed to military action both before the war (logistic coefficient $=-.26$, s.e. $=.12, p<.05$ ) and during the war $(-.26$, s.e. $=.13, p<.05)$. But for respondents who chose the Hitler analogy, older respondents tended to support military action more than younger respondents both before the war $(.06$, s.e. $=.14)$ and during the $\operatorname{war}(.07$, s.e. $=.10)$, though neither coefficient is significant. The special appeal of the Hitler analogy to older respondents "turns around" the relationship between age and support for the war, though it does so only in a relative sense when compared with those who rejected the Hitler analogy.

\section{Effects of Education, Gender, Race, and Region on Support for Gulf War}

Although our primary concern is with the relationship between cohort and support for military action in the Gulf War, Table 4 reveals other findings that are important in understanding the sources of support for war prior to January 16 and how support was transformed once the bombing began. Before January 16, educational level showed no relationship to support for military action. However, during the war the relationship is significantly negative, i.e., the lower the education, the greater the support. Examination within educational categories indicates that highly-educated Americans did not change their position on military action as a result of the initiation of the war, but that less-educated Americans moved strongly toward support of the military action. More precisely, the greatest increase in support for the President's decision to go to war came from those with high school graduation or some 
college experience (but not college graduation) - from what might be thought of as "middle America." Only among the most educated part of the population did the proportion opposing the war remain unchanged by the dramatic events that began on January 16.

In addition, before the war started, race, gender, and region were all lines of division in the total population: Blacks, women, and non-Southerners opposed military action more than did whites, men, and Southerners. However, once the war began the associations involving race and region essentially disappeared and the association with gender declined. This suggests that some combination of rallying around the President and promises of rapid success won over parts of the population initially opposed to military action.

Certain of these control variables could interact with cohort in affecting support for the war, e.g., better-educated younger respondents with greater knowledge of history might respond differently to the presentation of lessons from the past. However, none of the background variables interacts significantly with age either before the war or during the war. Thus, to the extent that cohort experience had any effect on support for the war, the effect does not appear to be located within particular categories of education, race, gender, or region.

\section{CONCLUSIONS}

Our investigation of the relationship between generation and attitudes toward the war with Iraq demonstrates both the strength and the weakness of the Mannheim hypothesis about the enduring effects of youthful experience. On the one hand, there is clear evidence that Americans who grew up during or in the aftermath of World War II found analogies to that war attractive when they were applied to Iraq's invasion of Kuwait, while those whose youth was influenced primarily by the Vietnam experience found the Vietnam War more relevant when confronted with the possibility of a major new military intervention by the United States. In each case, the collective memory of the last profound war experience seemed to continue to affect later cohorts until an equally profound new war experience began to construct a new collective memory for youths growing up at that time.

Nevertheless, the translation of these cohort effects into actual support for or opposition to the war is so faint as to be barely visible in our data. In formal terms, this is a result of the familiar phenomenon in social research in which relatively small but statistically significant relationships tend to disappear when their coefficients are multiplied one by another. Looked at more substantively, the effect of age on the appeal of a particular analogy is real and the relation of analogy preference to attitudes toward the war is also real and strong; but in the face of other forces the two effects are too weak to result in the simple relation between age and attitudes toward war that reasoning on the basis of generation leads one to expect. The most we can say is that the appeal of the World War II analogy to older cohorts reduced somewhat their opposition to war in the Persian Gulf, while the appeal of the Vietnam analogy to younger cohorts tempered their tendency to give full support to military action in the Gulf.

We can identify three possible explanations for why generational experience, acting through the appeal of analogies from the past, was not a stronger determinant of attitudes toward the Gulf war. One possibility concerns the link between choice of analogy and support for the war, but since that link is strong the main difficulties must lie elsewhere.

A second possibility concerns the link between cohort and choice of analogy. This relation is not so strong, although it is statistically significant and theoretically important. Expectation of a strong connection was based on earlier research by Schuman and Scott (1989) that showed substantial associations between age and spontaneous mentions of World War II and the Vietnam War to an open-ended question about important events and changes from the past half century. We replicated that finding in the current research by including the same question in our October and November surveys: The relationship between age and spontaneous mentions of World War II and the Vietnam War is considerably stronger than is the relationship between age and choice of analogy. ${ }^{11}$ However, the quite personal expe-

${ }^{11}$ Substituting mention of World War II versus mention of Vietnam as the dependent variable in Table 2 yields a coefficient for age of -.34 (s.e. $=.07$, $p<.001)$. The cross-tabulation of our dichotomous variable of old versus young cohorts against mentions of World War II versus mentions of Vietnam yields phi $=.32$, which is appreciably and significantly $(p<.001)$ stronger than that for the crosstabulation of the same age variable against analogy choice for the same subsample of the two months combined (phi = .17). 
riences that respondents remember when they spontaneously mention World War II or Vietnam to an open question about important past events may be only weakly related to more abstract memories about the general character of either war - the abstract memories having been drawn as much or more from secondary sources as from personal experience. In terms of current distinctions made by memory researchers (Tulving 1983), the one is "episodic," a type of memory based on personal experience, e.g., of having been in the Army during World War II, and the other is "semantic," a type of memory for the meanings of words and for knowledge generally, e.g., of World War II's occurrence and its reputed causes and consequences. We should not assume that the two types of memory are necessarily closely connected. The weaker association between age and analogy choice compared to that between age and spontaneous personal memories of a war may simply testify to this weaker connection.

The third possible explanation returns to earlier findings that indicate that age, at least in recent years, has had a negative relationship to support for military intervention elsewhere, with younger people more apt to give support to the wars in Korea and Vietnam. It is possible that young people, for both biological and social reasons, are more receptive generally to military and other forms of direct action. In formal terms, age would have a negative direct effect on support for the war (older people are less supportive), as well as an indirect positive effect via choice of the Hitler analogy (older people are more supportive), and the two would tend to cancel out. ${ }^{12}$

Finally, we should keep in mind that our results are partly a function of the actual course of the war with Iraq, once it was initiated. Had there been many American casualties, a protracted struggle, and an inconclusive outcome, the power of the Vietnam analogy would surely have

${ }^{12}$ Other important variables may have been omitted from our model, though it is difficult to identify additional factors that might change the age coefficients in Table 4 to an appreciable extent. For example, there were differences by political party affiliation in support for use of military force against Iraq (The Gallup Poll Monthly, Jan. 1991, p. 14), as there had been during the Vietnam War - the "partisan" factor identified by Mueller (1973) — but party identification is only slightly related to age $(r \approx .06$ based on several recent data sets). Thus a control for party identification would raise the relationship between age and support for the war only slightly. grown, perhaps especially among those who initially chose that analogy. Our findings are based on events as they actually happened and a conclusion about the relative weakness of past memories on support for the war can lay no claim to being a timeless generalization. Nevertheless, in the situation we studied, ideal in many respects for the exploration of the Mannheim hypothesis, we have demonstrated the influence of generational experience in directing attention to one historical analogy or another - and also its limitation in influencing support for policy choices. Rather than past experience controlling the present, the present controlled the past, as most Americans of all generations came to accept the analogy to World War II - an analogy that justified massive military action against an enemy that was almost unknown a few months earlier.

Howard SChuman is Professor of Sociology at the University of Michigan and a program director in the University's Institute for Social Research. His main research interests are in collective memory, changes in racial and ethnic attitudes, and the question-answer process in large-scale surveys.

Cheryl RIEGER is a Ph.D. candidate in sociology at the University of Michigan. With support from the University's Research Partnership Program, she is presently writing a dissertation on collective memory in Israel, Lithuania, and several other countries.

\section{REFERENCES}

Alwin, Duane F., Ronald L. Cohen, and Theodore M. Newcomb. 1991. Aging, Personality and Social Change: Attitude Persistence and Change Over the Life-Span. Madison: University of Wisconsin Press.

Barnes, Samuel H. 1972. "The Legacy of Fascism: Generational Differences in Italian Political Attitudes." Comparative Political Studies 5:41-57.

Campbell, Angus, Philip E. Converse, Warren E. Miller, and Donald E. Stokes. 1960. The American Voter. New York: Wiley.

Cantril, Hadley. 1951. Public Opinion: 1935-1946. Princeton: Princeton University Press.

Converse, Philip E. 1964 "The Nature of Belief Systems in Mass Publics." Pp. 206-61 in Ideology and Discontent, edited by D. E. Apter. New York: Free Press.

1987. "The Enduring Impact of the Vietnam War on American Public Opinion." Pp.53-75 in After the Storm: American Society a Decade After the Vietnam War, edited by The Institute of American Culture, Academia Sinica. Taipei, Republic of China: Institute of American Culture.

Danigelis, Nicholas L. and Stephen J. Cutler. 1991. "Cohort Trends in Attitudes about Law and Order: 
Who's Leading the Conservative Wave?" Public Opinion Quarterly 55:24-29.

Davis, James A. 1975. "Communism, Conformity, Cohorts and Categories: American Tolerance in 1954 and 1972-73." American Journal of Sociology 81:491-513.

Fishbein, M. and I. Ajzen. 1975. Belief, Attitude, Intention and Behavior. Reading, MA: Addison-Wesley.

The Gallup Poll Monthly. 1991. No. 304, Jan.

The Gallup Poll Monthly. 1991. No. 305, Feb.

Holsti, Ole R. and James N. Rosenau. 1980. "Does Where You Stand Depend on When You Were Born? The Impact of Generation on Post-Vietnam Foreign Policy Beliefs." Public Opinion Quarterly 44:1-22.

Jennings, M. Kent. 1987. "Residues of a Movement: The Aging of the American Protest Movement." American Political Science Review 81:367-82.

Krosnick, Jon A. and Duane F. Alwin. 1989. "Aging and the Susceptibility to Attitude Change." Journal of Personality and Social Psychology 57:41625.

Mannheim, Karl. [1928] 1952. "The Problem of Generations." Pp. 276-322 in Essays on the Sociology of Knowledge, by Karl Mannheim. London: Routledge and Kegan Paul.

Marwell, Gerald, Michael T. Aiken, and N. J. Demer- ath III. 1987. "The Persistence of Political Attitudes Among 1960s Civil Rights Activists." Public Opinion Quarterly 51:359-75.

Mueller, John E. 1973. War, Presidents and Public Opinion. New York: Wiley.

Ryder, Norman B. 1965. "The Cohort as a Concept in the Study of Social Change." American Sociological Review 30:843-61.

Schuman, Howard. 1972. "Two Sources of Antiwar Sentiment in America." The American Journal of Sociology, 78:513-36.

Schuman, Howard and Jacqueline Scott. 1989. "Generations and Collective Memories." American Sociological Review 54:351-81.

Smith, Jean Edward. 1992. George Bush's War. New York: Henry Holt and Company.

Toner, Robin. 1991. "The Unfinished Politician." New York Times Magazine, 14 Apr., pp. 42-43, 51, 57, 66-69.

Tulving, Endel. 1983. Elements of Episodic Memory. Oxford University Press.

Wagner-Pacifici, Robin and Barry Schwartz. 1991. "The Vietnam Veterans Memorial: Commemorating a Difficult Past." American Journal of Sociology $97: 376-420$.

Weil, Frederick D. 1987. "Cohorts, Regimes, and the Legitimation of Democracy: West Germany Since 1945." American Sociological Review 52:308-24. 